OSOBA | SAMOTNOŚĆ. MIĘDZY CODZIENNOŚCIA A MISTYKA

Filozofia ChrześcijańsKa • Tom 12, Poznań 2015

Uniwersytet im. Adama Mickiewicza w Poznaniu - Wydział Teologiczny

doi: $10.14746 / f c .2015 .12 .04$

\title{
JAKUB ŁOBOCKI
}

Uniwersytet Jagielloński

\section{Projektowanie egzystencji. Samotność. Właściwe bycie sobą?}

Project of Existence. Solitude. Authentic Being-one's-self?

Umiera się samemu.

Trzeba tedy czynić, jak gdyby człowiek był sam ${ }^{1}$.

Żyje się raz! Prawda ta dociera do nas zwykle nazbyt wcześnie. Z całą pewnością żyjemy właśnie teraz, z wysokim prawdopodobieństwem jedynie te(n)-raz. Jeśli dopuszczamy do siebie jakieś religijne domysły: ten raz jest dla nas istotny jako warunek jakości życia przyszłego czy życia wiecznego - jako bieżący i skończony nabiera wagi ze względu na nieskończoność i nie wolno go nam zmarnować. Jeśli nie poszukujemy sensu po stronie tego, co nieskończone, odczuwamy konieczność wydobycia sensu życia właśnie z jego niepowtarzalności - życie jako pojedyncze i skończone nabiera wagi ${ }^{2}$, daje nam niepowtarzalną szansę przeżycia go, której nie wypada zmarnować - w myśl zasady: żyje się raz, ale jeśli zrobisz to dobrze, raz wystarczy!

${ }^{1}$ B. Pascal, Myśli, tłum. Tadeusz Żeleński (Boy), Warszawa 2000, fragment 351 [63], s. 152.

${ }^{2}$ Nacisk na (po)wagę tego, co robimy ze swoim życiem, jest obecnie ogromny i porównać go można, zdaje się, jedynie do tego, jaki w sferze moralnej kładł na swych wiernych Kościół, każąc im pamiętać o śmierci, która przyjdzie niespodziewanie niczym złodziej, a także o sądzie i piekle, owym ostatecznym rozliczeniu i wiecznie powracającym (samo)potępieniu, od którego nie będzie ucieczki. Obecnie - w wyniku sekularyzacji współczesnych społeczeństw - ważność każdej chwili naszego życia nadaje nie tyle nieskończoność, ile skończoność właśnie. Życie nie jest żadnym przygotowaniem jakiegoś później, nie ma co liczyć na niczyją łaskę i łudzić się, że miłosierny Bóg ostatecznie wybawi każdego nieudacznika i dopuści go do wiecznej szczęśliwości. Nasze szczęście może się ziścić jedynie (te)raz podczas naszej pojedynczej i niepowtarzalnej ziemskiej egzystencji i co więcej: to, czy się ziści, zależy jedynie od nas. 


\section{POTOCZNE DLA WSPÓłCZESNOŚCI ROZUMIENIE PROJEKTOWANIA EGZYSTENCJI}

\section{1. Życie według projektu}

Z uwagi na skończoność niepowtarzalnego życia głównym problemem człowieka stał się czas. Już nie tylko egzystuje się w czasie, ale też ma się czas. Mój czas, czas przede mną, czas, który pozostał. Czas ten jest wymiarem naszej egzystencji: zamyka ją w pewną możliwą całość, a zarazem czyni ją czymś dostępnym, naszą własnością z którą możemy coś zrobić, którą należy zagospodarować. Określamy własną egzystencję przez to, co robimy ze swoim czasem. Ponieważ zaś czas ten jest policzalny (policzony), należy go właściwie wykorzystać. $Z$ tego samego powodu jesteśmy odpowiedzialni ${ }^{3}$ za to, jak nim zarządzamy. „Czas to najbardziej wartościowy element naszego majątku”. Od nas tylko zależy, na co go poświęcamy i komu ofiarowujemy - zawsze go jednak wytracamy i mamy go coraz mniej - dlatego też powinniśmy być w tym jak najbardziej rozsądni.

Najrozsądniejszym rozwiązaniem opanowania problemu przemijania wydaje się przygotowanie strategii optymalnego wykorzystania całości czasu, który pozostał. Im wcześniej, tym lepiej. Taka stworzona przez siebie oraz narzucona samemu sobie strategia optymalnego spełnienia własnego życia nosi nazwę projektu egzystencjalnego.

Odpowiednie zaprojektowanie egzystencji składa się z obrania sobie celu głównego (najbardziej własnego zadania, ,powołania”), określenia celów pomniejszych (tego, co chce się osiagnąć, nauczyć przed śmiercia) oraz szeregu rozwiązań społecznych, takich jak: wybór kierunku wykształcenia, pracy, miejsca zamieszkania, stylu życia, jak i podjęcia ważkich decyzji egzystencjalnych (należących do schematu przeciętnej egzystencji): wyboru między byciem samemu a związkiem, posiadaniem lub nie potomstwa, między osiadłym trybem życia a przemieszczaniem się itp., a wreszcie określenia preferencji tego, między

\footnotetext{
${ }^{3}$ Odpowiedzialność za to, co zrobimy z własnym życiem w kontekście jego pojedynczości i niepowtarzalności (jest wszystkim, co mamy, tym co mamy najcenniejszego), ciężarem gatunkowym można przyrównać jedynie do ciężaru dokonania czynu w perspektywie jego „wiecznego powracania", znów i znów przeżywania go, które w przypadku błędu prowadzi do obłędu, do piekła - i choć ta ekstremalna sytuacja wydaje się niemożliwa, zdaje się, że im bardziej rozwinięta jest (samo)świadomość, tym bardziej skłonna jest odczuwać wagę odpowiedzialności zarówno pojedynczych czynów, jak i odnalezienia oraz wypełniania swojej życiowej misji. Odpowiedzialność ta jest nie tylko wielka pod względem ciężaru osobistego, ale także ważka dla ludzkości jako takiej - ponieważ to, co mogę przede wszystkim zrobić dla innych, to zadbać o samego siebie, przede wszystkim zaczać od siebie.

${ }^{4}$ Por. Ph. Zimbardo, J. Boyd, Paradoks czasu, tłum. A. Cybulko, M. Zieliński, Warszawa 2009, s. 17.

${ }^{5}$ „Jesteś jedyną osobą, która może sprawić, by twój czas miał znaczenie. Jeżeli nie ty, to kto? Jeżeli nie teraz, to kiedy?" - tamże, s. 29.
} 
kogo i co w naszej codzienności rozdysponujemy nasz czas (na co przeznaczamy swój czas, zgodnie ze swoim przeznaczeniem).

Projekt egzystencjalny zakłada zatem uprzedni namysł wybiegający w przyszłość, którego celem jest danie/dawanie sobie odpowiedzi na pytanie ,jak żyć?”, wyznaczenie/wyznaczanie sposobu, w jaki będzie można optymalnie przeżyć i spełnić życie i siebie jako jednostkę. Budowa takiego projektu jest wybieraniem, którego efektem staje się ukierunkowanie wszystkich kolejnych wyborów. W tym sensie jest stanowieniem wartości. Właściwie wykreowany projekt staje się sensem życia, a wypełnienie go jego celem. Fundamentami takiej postawy są: samoświadomość i wiara we własne możliwości, siła woli, odpowiedzialność, praca nad sobą, walka z przypadkiem - motorem: chęć określenia i stworzenia siebie, bycia kimś poprzez dokonania. Projekt taki jest ściśle związany z budowaniem własnej tożsamości.

Nie każdy potrafi spojrzeć w swoją przyszłość, tym bardziej spojrzeć na swoje życie jako całość. Stąd, choć nie będziemy podziwiać nikogo za to, że potrafi zaplanować sobie weekend, jesteśmy skłonni cenić jako odpowiedzialnego i przewidującego kogoś, kto już w młodości myśli i zabiega o zapewnienie sobie takiej emerytury, która na starość czyniłaby go przynajmniej niezależnym finansowo i nieuciążliwym dla bliskich. Projektowanie życia poprzez wyznaczenie sobie pewnego szlaku istotnych dokonań jest społecznie wartościowane wyżej niż troszczenie się o siebie z dnia na dzień. O ile bycie zapobiegawczym może mieć więcej wspólnego z zachowawczością i interesownością, o tyle bycie przewidującym jawi się jako mające wiele wspólnego z rozsądkiem, wolnością „,do" i odpowiedzialnością, a jako pytające o to ,jak żyć" także jako etyczne ${ }^{6}$. Chęć dobrego wykorzystania własnego czasu wypływa, jak się zdaje, z jakiegoś wyższego poziomu świadomości, z przebudzenia samoświadomości, jest wartościowana wyżej - nie każdy to potrafi, ale każdy powinien?

Potrzebę samookreślenia rodzą w nas wymagania społeczne: rodzina, znajomi, konieczność edukacji ${ }^{8}$, pracy, przynależności do społeczeństwa w ogóle: owo

\footnotetext{
${ }^{6} \mathrm{Na}$ temat fundamentalnego znaczenia tego pytania dla etyki - zob. J. Filek, Filozofia jako etyka. Eseje filozoficzno-etyczne, Kraków 2001, s. 168-182.

${ }^{7}, \mathrm{~W}$ interesie społecznym i własnym, jednostka może i powinna się stawać w coraz bardziej dosłownym sensie «ekspertem» w sprawach kierowania własnym życiem i rozwojem, lub - mówiąc inaczej - powinna zmierzać świadomie do nabywania kompetencji biograficznej. Podstawą tej kompetencji jest zarówno wiedza potoczna i naukowa, jak i doświadczenie osobiste jednostki" - Z. Pietrasiński, Rozwój z perspektywy podmiotu, w: Rozwój psychiczny człowieka w ciagu życia. Zagadnienia teoretyczne i metodologiczne, red. M. Tyszkowa, Warszawa 1988, PWN, s. 109. Jak się wydaje, dziś każdy ma dość szerokie kompetencje biograficzne, które są stale zwiększane chociażby poprzez media. Brak takich kompetencji wiązany jest ze znacznie mniejszymi szansami adaptacyjnymi, uzyskania wyższej pozycji społecznej czy odniesienia sukcesu. Intensyfikacja życia, zwiększenie wartości swojego CV, a przez to i orientacja na przyszłość stała się „,nową” normą. Zob. Ph. Zimbardo, J. Boyd, Paradoks czasu, dz. cyt., s. 131.

${ }^{8}$ Dom i szkoła zwyczajowo wpajają w nas nawyki samokształcenia i samowychowania. Zmie-
} 
„coś trzeba w życiu robić”; wzmaga poczucie skończoności bycia, życie wobec śmierci: chęć zaistnienia, bycia kimś, pozostawienia po sobie śladu (choćby tych paru artykułów...); wspomaga potoczna wiedza psychologiczna9: gdzie poznaj samego siebie znaczy często stwórz siebie, określ siebie i próbuj stać się taki, jakim chciałbyś być, zachowuj się poprawnie, bądź asertywny, pewny siebie, myśl pozytywnie, bądź kreatywny, przedsiębiorczy, pracowity, a więc nie tylko stań się kimś, ale wykreuj siebie tak, by się wybić, osiąnnąć sukces: przede wszystkim stawiaj sobie poprzeczkę wysoko i nie przestawaj marzyć - dąż, dąż nieustannie!

Dobrze zapowiadający się człowiek powinien odpowiedzialnie (konsekwentnie) i odpowiednio (należycie) zrealizować to, co zapowiedział. Młody człowiek pnący się po szczeblach kariery jest kimś obiecującym, kimś mającym przyszłość - potrzeba mu tylko tego, by jej nie zmarnował ${ }^{10}$, by wypełnił swoje obietnice. Owo „nie zmarnował” jest równoznaczne z ,przeżył życie dobrze” i jako takie stanowi kryterium społecznego usprawiedliwienia jego wolności, a zarazem odgrywa rolę mobilizującej go presji. Presja społeczna (np. nacisk rodziców na edukację dziecka) jest jedynie powieleniem presji osobistej płynącej ze świadomości niepowtarzalności życia oraz potrzeby sensu.

Realizacja projektu siebie jako pogoń za szczęściem „nieustannie zaprząta nasze myśli, pochłania lwią część naszego życia, nie zwalnia tempa i nie uznaje przestojów”"11, dlatego też jest ona „zajęciem absorbującym, frustrującym, obarczonym ryzykiem i wymagającym znacznego nakładu energii”" ${ }^{\prime 2}$. Niepowtarzalność numeryczna życia wprawdzie nie obliguje nas do tego, by nasze życie było

nił się jednak wzór przeciętności - to, co kiedyś stanowiło dorobek ludzi „dobrze wykształconych”, dziś uznaje się za wiedzę i umiejętności standardowe, bez których zostaje się zepchniętym na „margines" społeczeństwa, np. znajomość języków obcych, zainteresowanie sportem, zdrowiem, duchowością.

${ }^{9}$ Zimbardo oraz Boyd tak reklamują swoją książkę poświęconą czasowi: „Ta książka mówi o przeżyciu życia w sposób pełny, o wyciśnięciu go z każdego roku, miesiąca, godziny, minuty i sekundy, jakie są ci dane”. A dalej: „Książka ta jest przewodnikiem po tym, jak inwestować w swoją przyszłość. Czas ma znaczenie, nieważne kim jesteś, gdzie mieszkasz, ile masz lat i czym się zajmujesz. Niezależnie od tego, czy pijesz w samotności, czy też jesteś przywódcą narodów, czas ma znaczenie. Czy jesteś samotną matką, dyrektorem, nauczycielem, studentem, czy więźniem, czas ma znaczenie. Możesz być wyluzowanym hedonistą, czy też żwawo pnącym się do góry, pracoholikiem typu A, czas ma znaczenie. Twój czas jest cenny. Odbywasz tę podróż tylko raz, jest więc niezwykle istotne byś wykorzystał ją możliwie jak najlepiej” - Ph. Zimbardo, J. Boyd, Paradoks czasu, s. 26 i 29.

10 „Rozwój w wieku dojrzałym zdaje się nie regułą życia, a jedynie możliwością, która może zostać nie zrealizowana. [...] od pewnego momentu życia absolutnie niezbędny [warunek rozwoju, to - J.Ł.]: osobiste świadome zaangażowanie człowieka we własny rozwój. [...] bez takiego zaangażowania człowiek staje się «produktem ubocznym własnego życia»” - E. Sujak, Rozważania o ludzkim rozwoju, Kraków 1998, s. 12-13.

${ }^{11}$ Z. Bauman, Sztuka życia, thum. T. Kunz, Kraków 2009, s. 7.

12 Tamże, s. 11. 
niepowtarzalne również treściowo, „nieludzko” oryginalne, ale do tego, by było intensywne - pełne dokonań. Stąd może ono prowadzić do wyczerpania i depresji, może się załamać i zakończyć niepowodzeniem. Załamane projektowanie siebie może zacząć podawać samo siebie w wątpliwość. Podanie w wątpliwość wartości projektowania egzystencji zwykle skierowuje ją na drogę życia z dnia na dzieńn ${ }^{13}$.

\section{2. Życie bez projektu}

„Sielankowa” wizja człowieka żyjącego z dnia na dzień, nieprzejmującego się własną śmiercią ${ }^{14}$, nieodczuwającego potrzeby jak najintensywniejszego wykorzystywania czasu, ale „po prostu” żyjącego, jest pociagająca nade wszystko jako wytchnienie od nieustannego dążenia do czegoś. Marzymy o tym, by na powrót móc stać się kimś wolnym od obsesji śmierci oraz od wynikającej z niej obsesji uzasadniania i usensowniania egzystencji i jej intensyfikacji. Ideałem wydaje się tu człowiek pierwotnie prosty, którego wolność polega na: codziennym i każdorazowym wybieraniu bądź odrzucaniu tego, co mu życie przynosi, otwarciu na spotkania i chwytanie przypadków, poddawaniu się urokowi chwili, oddawaniu się w ręce losu. Człowiek taki nie decyduje o tym, czy chce związać się z kimś czy też pozostać singlem, którą to decyzję następnie realizuje, otwierając się na możliwość zakochania w kimś i jakby wywołując je bądź zamykając swoje serce, ale wiąże się z kimś dlatego, że spotkała go miłość, lub pozostaje sam dlatego, że miłości nie napotkał. Nie szacuje, na jaką liczbę przyjaciół może sobie pozwolić, by miał czas dawać im wszystkim siebie w należycie głęboki i troskliwy sposób przy utrzymaniu zadowalającej (nienadużywającej) obie strony regularności spotkań. Stanowi on przeciwieństwo człowieka programowego i wyrachowanego, który potrzebuje wpierw określić swoje możliwości, oszacować zyski, wyznaczyć cele i zasady, a następnie wprowadza plan w życie. Projekt egzystencjalny jest właśnie taką teorią poprzedzającą życie.

Przeciwieństwem człowieka teoretycznego nie jest człowiek praktyczny, gdyż - jak widać - są to właściwie dwie strony tego samego medalu - ale człowiek spontaniczny, który jest swobodny, uczuciowy i przygodowy. O ile czło-

${ }^{13}$ Zob. tamże, s. 8 i nn. Na przykład, coraz więcej bogatych ludzi odczuwa, że pieniądze nie dają szczęścia. Coraz częściej spotkać można „ludzi biznesu” w średnim wieku, którzy postanawiają porzucić swoją karierę i radykalnie zmienić własne życie - zostają wolontariuszami, zakładają fundacje i poświęcają się innym czy też decydują się na wyjazd do krajów słabo rozwiniętych w poszukiwaniu prostego, ale i trudnego/twardego życia, licząc na to, że objawi im ono swoja, zapomnianą już przez „białego człowieka”, pierwotną wartość. (Takie postępowanie niewątpliwie jest rodzajem „kompleksu” Rousseau). Na temat różnicy między projektującym Zachodem a dostosowującym się Wschodem zob. R.E. Nisbett, Geografia myślenia, thum. E. Wojtych, Sopot 2009, krótko s. 67, obszerniej całe rozdziały 3 i 4.

${ }^{14}$ Por. M. Heidegger, Bycie i czas, thum. B. Baran, Warszawa 1994, s. 357. 
wiek programowy walczy z przypadkiem lub ewentualnie wykorzystuje go do swych celów, człowiek spontaniczny pozostaje otwarty i wedle woli daje się nieść przypadkowi - sam nie wie, do czego go to doprowadzi, co zresztą nie ma znaczenia - gdyż człowiek ten do niczego nie dąży, nie spieszy się, przerwanie jego życia w dowolnej chwili nie krzyżuje mu ,żadnych” planów, a jedynie w przykry sposób przerywa jego święte teraz. Nie można odmówić takiemu człowiekowi posiadania jakości, jest on jakoś określony przez swe wybory, a jednak nie jest zainteresowany tym, jak one go określają, jak go podsumowują. Jego tożsamość jest mu raczej dana, a nie zadana ${ }^{15}$. Jest przeciwieństwem, antypodami wobec obciążonego swą egzystencją człowieka interesu - i jako taki jest jego tęsknotą za lekkością i wytchnieniem.

Nie zaprzeczając temu, że człowiek spontaniczny zaistniał gdzieś w sposób spontaniczny i żyje obok człowieka teoretycznego, możemy zapytać: jaka jest szansa na to, że człowiek programowy zdoła programowo stać się spontaniczny? Czy możliwa jest taka przemiana tożsamości? Czy ogranicza się ona jedynie do zmiany przyjętej perspektywy czasu?

\section{Usprawiedliwienie wolności}

Pozostawiwszy te pytania bez odpowiedzi, powróćmy do człowieka projektującego siebie, który nie stracił wiary. Jeśli jest dzielny, nie załamie się pod naporem stresu i dopełni swego, to realizowanie egzystencjalnego projektu stanie się dlań samorealizacją. Człowiek ten przekonany jest, że to, czy umierając będzie się czuł spełniony, zależy głównie od niego samego: od tego jak wypełnił to, czemu dał wiarę, czy żył zgodnie z własną filozofią życia. Złośliwi powiedzieliby: a zatem zależy od tego, jakiej ideologii dał się uwieść - w tym sensie umierający islamski terrorysta umiera śmiercią spełnionego, spełnił do końca swą egzystencję, zadanie, które sobie obrał. Wydaje się, że faktycznie nie ma większego znaczenia dla samego poczucia spełniania to, skąd przyszło do nas nasze zadanie, czy jest ono nasze jako wykreowane przez nas, czy też nasze jako przez nas przyjęte i zadecydowane - w obliczu śmierci istotne jest to, że było nasze i że udało się nam je wypełnić. Jeśli nie zwątpimy, nie zaprzemy się swej wiary, jego wypełnieniu towarzyszyć będzie poczucie szczęścia, świadomość wypełnienia swego zadania jako jednostki, samousprawiedliwienia naszej egzystencji.

Czymś innym jednak jest wypełnienie projektu egzystencji i towarzyszące mu samopoczucie usprawiedliwienia jej przed sobą - czymś innym zaś jej usprawiedliwienie społeczne. Jaka jest możliwość utrzymania własnej wiary wobec przemocy oceny społecznej? Jaką moc musiałby mieć egocentryzm, by stać go było na taką samotność, przeciwstawienie się innym i podjęcie ryzyka tego, że racja może leżeć po ich stronie - być może dopiero moc geniuszu lub szaleń-

\footnotetext{
${ }^{15}$ Por. Z. Bauman, Sztuka życia, dz. cyt., s. 28.
} 
stwa. Stąd usprawiedliwianie własnej wolności (tego jak ją zagospodarowaliśmy) przed innymi ludźmi wydaje się niemal nieuchronne.

Nierzadko zdarza się, że egzystencja człowieka oceniana i usprawiedliwiana jest z uwagi na jego dzieła - za samą wagę wytworów i ich wkład w kulturę, a pomija się to, jakie życie pędził sam twórca, a przede wszystkim to, jakim był człowiekiem (wynosi się go ponad dobro i zło) ${ }^{16}$. Zwykle jednak usprawiedliwia i podziwia się kogoś właśnie za to, jakim był człowiekiem, jak wysoko był uspołeczniony, pomimo braku jego wkładu w kulturę (choćby takiego, że jego postępowanie nie jest dość szeroko znane jako przykład dla innych). Chimeryczny i egoistyczny twórca podążający sobie tylko wiadomą (samotną) ścieżką ${ }^{17}$ ryzykuje, że jeśli jego dokonania nie zostaną uznane społecznie, jego egzystencja zamiast wymiaru osiagnięcia sukcesu, nabierze w oczach innych wymiaru upadku i moralnego zepsucia. Człowieka nietworzącego niczego, a dbającego jedynie o to, by „żyć dobrze" (dobrze w sensie moralnym, utrzymywania się w granicach społecznych standardów tolerancji), z dużym prawdopodobieństwem czeka los zaginięcia w odmętach ludzkiej niepamięci. Wydaje się zatem, że także dla niego większą wartość miałoby usprawiedliwienie własnego życia przed sobą każdorazowe czynienie tego, co uważa za słuszne. Co jest szczęściem dla jednego, może być koszmarem dla drugiego. Można zapytać: jaką zatem wartość ma społeczne usprawiedliwianie wolności? I odpowiedzieć na to pytanie: żadną, a zarazem: wysoką.

\section{Potoczne rozumienie projektowania egzystencji a samotność}

Rola samotności w obraniu projektowania egzystencji za swoją życiową drogę wydaje się bardzo zróżnicowana i uzależniona od konkretnych odpowiedzi na pytanie o to, ,jak żyć?”. Zarówno poziom samodzielności samego projektowania, jak i poziom samotności jego realizacji zależy od samego wyboru tego, czego chcemy dokonać: od tego, czy przejmiemy wytyczne projektu jako dziedzictwo pozostawione przez innego/innych (autorytetu, duchowego mistrza, religię), czy też będziemy dążyć do ujawnienia go na drodze indywidualizacji i rozwoju osobistego (samopoznania, posłuszeństwa sumieniu, powołania); od tego, czy będzie to projekt, w który z konieczności włączeni są inni (praca w grupie, praca społeczna, głębokie relacje, ale i inni jako publiczność, rzesza fanów, warunek sławy), czy też samotna droga twórcy, który mniej lub bardziej zapomniał o in-

${ }^{16}$ Jako przykład można by podać wielu artystów, których rażący sposób życia był znoszony jedynie $z$ uwagi na ich dzieło. Podobnie szefa firmy czy naukowca można cenić za jego osiagnięcia, wkład w rozwój firmy, nauki, abstrahując od jakości personalnych kontaktów z nim, będąc gotowym na tym polu wiele mu „wybaczyć”.

${ }^{17}$ Romantyczny mit niezrozumianego za życia i skazanego na samotność, a docenionego przez ogół dopiero pośmiertnie twórcy (wyprzedzającego swą epokę) wydaje się nadal dominującym modelem twórcy, geniusza jako takiego. 
nych (iluzorycznie: chcąc się od innych odróżniać, lub realnie: zatracając się w sobie, w swoich ideach i dążeniach). Pomimo tej różnorodności projektujących egzystencję łączy maksyma: moja egzystencja jest w moich rękach. Aby projektowanie w ogóle było możliwe, człowiek musi przyznać, że jego los leży w jego rękach, poczuć się nie tylko zdolny, ale i zobligowany do bycia ostateczna, samodzielną (a w tym sensie i samotną) instancją odpowiadającą za jakość całości własnego życia. Poczucie to czyni go samotnym (będącym u siebie w swej intymności) w każdej chwili jego życia, w każdym związku, każdym zgrupowaniu z innymi. Choć żyje z innymi, musi czynić tak, jak gdyby był sam.

Życie jednostki jako jej własne i jedyne ma dla niej wartość absolutną. Życie innych jest sprawą innych. Każdy jest kowalem własnego losu i zbieraczem własnego duchowego miodu. Nie chcemy się angażować i poświęcać temu, co nie przyniesie nam jakichś osobistych profitów „wzrostu”. Nie naraża się życia na utratę cennego czasu. Inni ludzie albo coś wnoszą w nasze życie, albo niczego nie wnoszą. Dlatego stroni się od ludzi nieodpowiedzialnych (,wampirów energetycznych"), którzy nie rozumiejąc konieczności wymiany dóbr, biorą, nic w zamian nie dając. Ponieważ sam doskonale rozumiem, że dla każdego jego życie jest najważniejsze, nie mam pretensji do innych, że nie zajmują się mną tak jak sobą, oczekuję jednak, że i oni będą rozumieli, że nie są dla mnie ważniejsi niż ja sam. Największą odpowiedzialnością i powinnością jestem ja sam wobec siebie. Jeśli trwonię swój czas, poświęcając go innym, bez „żadnego" zysku, moja sprawa - widocznie niesie mi to szczęście - programowe działania charytatywne wobec innych są rodzajem inwestycji w siebie i jako takie moga być jednym z ważnych punktów mojego projektu (czy CV) ${ }^{18}$. Dlatego heroizm współczesnego człowieka nie polega na niesieniu pomocy innym, próbach zmiany sytuacji społecznej - polega na ,życiu na własny rachunek i obywaniu się bez pomocy innych"19. Twoje szczęście jest w tobie! Twoja wolność nie potrzebuje innego, wychodzi i zaczyna od siebie, i jest $z$ tego dumna ${ }^{20}$.

\section{Przejście}

Przedstawione powyżej potoczne dla współczesności rozumienie projektu egzystencjalnego (to jak Się go rozumie) niewątpliwie jest echem Sartreowskiego (przez to pośrednio i Heideggerowskiego) egzystencjalizmu oraz myśli Frie-

18 „Ja-jako-ostateczny-beneficjant może być w zasadzie dowolnie rozłożone w przestrzeni i czasie. Mogę, na przykład, troszczyć się o innych albo o jakąś większą strukturę społeczną. Nic nie ogranicza mnie do mnie samego jako przeciwieństwa nas" - D.C. Dennett, Odczarowanie. Religia jako zjawisko naturalne, tłum. B. Stanosz, Warszawa 2008, s. 215 (zob. także dotyczący tego fragmentu przypis).

19 A.R. Hochschild, The Commercalization of Intimate Life, Berkeley 2003, s. 21 i nn, za: Z. Bauman, Sztuka życia, dz. cyt., s. 190.

${ }^{20}$ Zob. J. Filek, Filozofia jako etyka. Eseje filozoficzno-etyczne, dz. cyt., s. 71. 
dricha Nietzschego. Chcąc utrzymać to rozumienie w takiej formie, w jakiej funkcjonuje ono w przestrzeni społecznej (Się), a zatem w formie „zdegenerowanej”, celowo nie odnosiłem się dotychczas do żadnych konkretnych myśli tych filozofów, nie dokonywałem genealogii, rekonstrukcji tego rozumienia poprzez powrót do źródeł jego inspiracji czy przedstawienia jego dziejów. Teraz, kiedy została już przeprowadzona diagnoza potocznego rozumienia, proponuję udać się z wizytą do Martina Heideggera, - który, jak wiadomo, zaakcentował filozoficznie pojęcie „projektu” oraz „egzystencji” - a tym samym dokonać wyjścia z poziomu rozumienia potocznego oraz przejścia na poziom ontologiczny, co - jak mniemam - będzie zgodne z zamysłem tego filozofa.

\section{HEIDEGGEROWSKIE ROZUMIENIE PROJEKTOWANIA EGZYSTENCJI}

\section{Krytyka potocznego rozumienia projektowania egzystencji}

Według Martina Heideggera zarówno projektowanie egzystencji jako możliwej do określenia i urzeczywistnienia całości, jak i spontaniczne życie z dnia na dzień bez projektu wynikają z niewłaściwego rozumienia bycia ku śmierci oraz niezupełności skończonego jestestwa, a zatem ze złego rozumienia samej egzystencji. Postarajmy się zrozumieć, co to wszystko znaczy.

Człowiek (Dasein, jestestwo), który ma jakiś projekt na siebie, swoją niezupełność pojmuje jako zaległości wypełnienia owego projektu, swoje zadanie zaś jako konieczność niwelacji zaległości. Projekt rozumiany jako zaległości do nadrobienia jest projektem pewnego bytu, który - choć już jakoś określony - nie został jeszcze urzeczywistniony. Coś poprzez projekt już należy do tego bytu, jest mu przypisane, ale właśnie jeszcze tego brak. Taka zaległość to dług, który należy stopniowo spłacać poprzez realizację, wypełnianie braku. W tym sensie zaleganie oznacza „niebycie-jeszcze-zebranym czegoś współprzynależnego”21. Wypełnienie projektu polega na wykończeniu bytu, jakim sami jesteśmy, poprzez uzupełnienie ${ }^{22}$, dodawanie, które dąży do osiągnięcia pewnej sumy jako całości wypełnienia założonego planu. Rozumienie siebie w ten sposób sprawia, że bez pomysłu na siebie czujemy się jeszcze „nikim”, potrzebujemy się ulepszyć, zaś konstruując siebie i budując, staramy się wypełnić dostrzeżone w sobie braki, ukończenie budowy utożsamiając ze szczęściem. Sprowadza to codzienne bycie do czegoś w rodzaju paniki przed czynnościami nieistotnymi i nieustannego poszukiwania tego, co naprawdę ważne do zrobienia - przenosi troskę o własne bycie-w-świecie na poziom troski o jak najintensywniejsze wykorzystanie i zagospodarowanie przyszłego czasu. Po nadrobieniu zaległości człowiek gotowy,

\footnotetext{
${ }^{21}$ M. Heidegger, Bycie i czas, dz. cyt., s. 341.

22 „Istniejący niedobór maleje przez stopniowy dobór” - tamże.
} 
spełniony, skończony jako pewna całość powinien zakończyć własne życie. Dzieło sztuki powinno być ukończone, a by było ukończone, praca nad nim musi być zakończona, a nie przerwana.

Taki (budowlany) sposób rozumienia niezupełności jestestwa jest według Heideggera sprowadzaniem jestestwa do poziomu czegoś wewnątrzświatowo poręcznego (narzędzia, „przedmiotu”), czym można manipulować, a zatem czegoś do zrobienia na poziomie ontyczno-egzystencyjnym ${ }^{23}$ (bytu, świata), nie zaś ontologiczno-egzystencjalnym (bycia). Projekt taki jest zatem projektem egzystencyjnym, a nie egzystencjalnym. Zastosowanie go odbiera ludzkiemu byciu (Dasein) jego egzystencjalny charakter (ową różnicę ontologiczną: różnicę między bytem a byciem). Zajmowanie się czymś, organizowanie i zarządzanie jest przedontologicznym, egzystencyjnym rozumieniem troski ${ }^{24}$. Troska o samego siebie jako wola, życzenie, pociagg i gonitwa ${ }^{25}$ powoduje upadanie jestestwa w świat i blokuje właściwy dostęp do siebie jako egzystencji i swoich egzystencjalnych możliwości. Egzystujące jestestwo „,charakteryzuje się nie faktem posiadania możliwości, ale bycia swoimi możliwościami"26, a być swoimi możliwościami, nie oznacza znać te możliwości (mieć je), ale znać siebie ${ }^{27}$.

Będący przeciwieństwem dla człowieka projektującego człowiek żyjący w zapomnieniu o śmierci, żyjący dzień-po-dniu ${ }^{28}$, również w niewłaściwy sposób troszczy się o własne bycie. Takie jestestwo jest zawsze niedokończone, dopiero śmierć je faktycznie zakończy i tworzy z niego post mortem pewną skończoną (przerwaną) całość. Nie oznacza to wcale spełnienia, osiagnięcia gotowości - „zwykle kończy się ono niedopełnione lub zdezintegrowane i zużyte”29, a czasy swej dojrzałości i świetności ma już dawno za sobą. Takie skończenie nie oznacza również właściwego troszczenia się o bycie. Bycie w taki sposób zasłania bycie ku własnym możliwościom poprzez wybieranie spośród propozycji przedstawionych przez świat i opinię publiczną. Wynika z pierwotnego rzucenia jestestwa w świat i jest pierwotnym modusem troski. Dla tak będącego jestestwa

\footnotetext{
${ }^{23}$ Projektowanie jako opanowywanie, podporządkowywanie sobie świata, narzucenie mu własnego celu, współgra z podejściem cywilizacji technicznej.

${ }^{24}$ Tamże, s. 80.

${ }^{25}$ Zob. tamże, s. 259, 274-278.

${ }^{26}$ E. Levinas, Odkrywajac egzystencję z Husserlem i Heideggerem, thum. E. Sowa, M. Kowalska, Warszawa 2008, s. 70-71.

27 Tamże, s. 71.

${ }^{28}$ Życie z dnia na dzień charakteryzuje się nastrojem „obojętności, która niczemu się nie poświęca, do niczego nie popycha i zdaje się na to co dzień niesie, a przy tym w pewien sposób wszystko akceptuje. [...] Obojętność, która może iść w parze z krzątaniem się do upadłego, musimy ostro odróżniać od spokoju ducha”. Oraz: „Powszedniość oznacza owo «jak», zgodnie z którym jestestwo «żyje z dnia na dzień». Jednostajność powszedniości bierze za odmianę coś, co właśnie przynosi [każdy] dzień" - M. Heidegger, Bycie i czas, dz. cyt., s. 484 i 519. Zob. także: s. 486, $572-573,576$

${ }^{29}$ Tamże, s. 344.
} 
jego „«kto» stanowi problem nie tylko ontologicznie, ale pozostaje zakryte także ontycznie" 30 . Nawet na poziomie ontycznym nie jest dlań oczywiste, że jestestwo jest ,zawsze moje”. Będąc tak blisko świata, jestestwo jest sobie samemu najdalsze $^{31}$. Dla Heideggera taki stan bycia jestestwa jest właśnie pierwotnie upadłym ${ }^{32}$, odpadłym od samego-siebie byciem na sposób Siebie-Się ${ }^{33}$.

Społeczne usprawiedliwienie czyjejś wolności: to, co się uważa za sukces, a to, co za porażkę, utrzymuje się w przeciętności Się. „Ta przeciętność wyznacza wszystko, na co można i wypada się odważyć, pilnie zważa na wszelkie wybijające się wyjątki. Każda przewaga zostanie po cichu zniwelowana. Wszystko, co głębokie, zostanie $\mathrm{z}$ dnia na dzień wygładzone do postaci dawno znanej. Wszystko, co wywalczone staje się obiegowe. Każda tajemnica traci swą moc" ${ }^{\prime 34}$. (Czyż nie żyjemy dziś w świecie globalnej przeciętności, gdzie to, co niegdyś stanowiło wiedzę dla wtajemniczonych, dziś dostępne jest dla wszystkich $\mathrm{w}$ internecie?). Czyż nie zniechęcamy się do własnych możliwości bycia, mówiąc „wszystko już było”, „nie jestem zdolny wnieść niczego nowego”, ,jest się jak wszyscy". Taką tendencję Heidegger nazywa „niwelacja wszelkich możliwości bycia" ${ }^{35}$. Jest ona skutkiem zniechęcenia racjami opinii publicznej, która nie wnikając w „różnicę poziomu i rzetelności”36, orzeka: wszystko było.

Zarówno gotowość, jak i niegotowość jestestwa w momencie kresu nie określają go we właściwy, egzystencjalny sposób jako całości. W pierwszym rozu-

30 Tamże, s. 166.

${ }^{31}$ Tamże, s. 23.

${ }^{32}$ Upadanie to przekład rozumienia bycia na bycie jako obecność. Zob. tamże, s. 291.

${ }^{33}$ Niewłaściwe rozumienie siebie nadchodzi od strony Się, w które jestestwo zrazu popadło. Upadek w Się jest położeniem pierwotnym i najbliższym jestestwu - jestestwo nie spadło z jakichś wysokości (zob. tamże, s. 249), ono już zrazu jest upadłe: jest Sobą-Się. Z pewnym uproszczeniem można by powiedzieć: tym, co zdołało nas zaspokoić, określić nasz sposób rozumienia, zanim zaczęliśmy rozumować samodzielnie, próbując się, pomimo kuszącej atrakcyjności takiej powszedniej wykładni, od niej odrywać. „Od początku jestestwo jest już zawsze odpadłe od samego siebie jako właściwej możności bycia Sobą i upadłe w «świat». Upadłość w «świat» oznacza zanurzenie we wspólnym byciu, gdy temu ostatniemu przewodzą gadanina, ciekawość, dwuznaczność" (tamże). Publiczna wykładania zamyka jestestwo, zarazem go w tym zamknięciu uspokajając, by nie mogło się poczuć nieswojo - w ten sposób wykorzenia je, odcina od „źródłowo-rzetelnych” relacji bycia do świata i do innych. „Ciekawość, dla której nic nie jest zamknięte, gadanina, dla której nic nie pozostaje niezrozumiane, dają sobie, tzn. tak będącemu jestestwu, rękojmię rzekomo prawdziwie «żywego życia»” (tamże, s. 245). Się szerzy się poprzez kuszące mniemanie, że „dostarcza ono strawy i przewodzi pełnemu i prawdziwemu «życiu»" (tamże, s. 251). To, co zewnętrzne wobec nas, niesie ze sobą pewne propozycje bycia. Różne dziedziny nauk humanistycznych (,filozoficzna psychologia, antropologia, etyka, «polityka», poezja, biografia i historiografia”), a także szeroki dyskurs pozanaukowy zajmuje się, ,na różne sposoby i w zmiennym zakresie zachowaniami, zdolnościami, siłami, możliwościami i losami jestestwa" (tamże, s. 23) w celu dania wykładni o b y c i e ludzkim.

${ }^{34}$ Tamże, s. 181.

${ }^{35}$ Tamże.

${ }^{36}$ Tamże. 
mieniu owa całość jest całością pewnego inżynieryjnie (technicznie) zaprojektowanego i dopełnionego bytu - a zatem czegoś poręcznego i obecnego - w drugim uobecnia się ona jako „całość” tylko dlatego, że dobiegła kresu. W obu przypadkach dokonuje się "obrócenie jestestwa w coś obecnego"37, ontycznego. Bycie i projektowanie całości jestestwa, aby było egzystencjalne, musi być czymś innym, czymś wymykającym się obecności (i poręczności).

Wprawdzie zadaniem do spełnienia przez jestestwo jest ono samo - to spełnienie jednak nie polega na wypełnieniu. ,Jeszcze nie”, którym jestestwo zawsze jest - nie jest zaległością do wypełnienia w sensie: ,jeszcze nie gotowy, ale możliwy do osiagnięcia, opanowania, przebycia"38. Ontologiczna niezupełność jestestwa polega na tym, że jestestwo musi stawać się tym, czym jeszcze nie jest, to znaczy właśnie dziać się - nie zaś wypełniać jakąś zaległość projektu i w tym sensie tworzyć siebie (stawać się). Właściwa jestestwu niezupełność nie domaga się uzupełnienia. „Jestestwo dopóki egzystuje, musi w swej możności-bycia zawsze czymś jeszcze nie być. Byt, którego esencję stanowi egzystencja, z istoty sprzeciwia się możliwości ujęcia go jako całego bytu”39. „To, co w jestestwie stanowi «niezupełność», stałą samoantycypację, nie jest ani zaległością sumatywnego doboru, ani wręcz czymś, co jeszcze-nie-stało-się-dostępne, lecz tym «jeszcze-nie», którym ma być jestestwo jako ten byt, którym jest"40.

\section{Egzystencjalne rozumienie projektu}

a) Pojęcie projektu

Jestestwo jako faktyczne jest od początku rzucone pośród możliwości, od początku się w nie angażuje - rozumie to, co możliwe, oraz rzutuje siebie poza narzuconą sytuację ${ }^{41}$. Projektowanie egzystencji - entwurf - dosłownie oznacza rzutowanie. Jest ono ściśle związane z rozumieniem - rozumienie „prze zawsze ku możliwościom"42. Wykracza poza swoją sytuację. Owo parcie jest rzutowaniem, na-rzucaniem. Dla Heideggera takie rzutowanie-projektowanie „nie ma nic wspólnego z trzymaniem się wymyślonego planu, wedle którego jestestwo urządzałoby swe bycie" ${ }^{\star 3}$. Nie ma także nic wspólnego z wybieraniem na rozdrożu jednej z dróg. Projektowanie, które ujmuje swoje możliwości tematycznie, odbiera im charakter możliwości i „redukuje do jakiejś danej, myślowej treści”44.

${ }^{37}$ Tamże, s. 351.

38 „Zatroskanie nastawione na coś możliwego ma skłonność do unicestwiania możliwości tego czegoś możliwego przez postawienie go do dyspozycji” - tamże, s. 366.

${ }^{39}$ Tamże, s. 328.

${ }^{40}$ Tamże, s. 343.

${ }^{41}$ Zob. E. Levinas, Odkrywajac egzystencję z Husserlem i Heideggerem, dz. cyt., s. 73.

${ }^{42}$ M. Heidegger, Bycie i czas, dz. cyt., s. 206.

${ }^{43}$ Tamże.

44 Tamże. 
Gdy tymczasem właściwe projektowanie ,podrzuca sobie możliwość jako możliwość i jako takiej pozwala być. Jest porywem ku temu, czego jeszcze nie ma. Jako projektowanie, rozumienie jest sposobem bycia jestestwa, pozwalającym na to, że jest ono swymi możliwościami jako możliwościami" ${ }^{45}$. Oznacza to nade wszystko, że jestestwo jest zawsze „czymś «więcej», niż aktualnie jest” w danym momencie jego „ciąłości bycia”, jego obecności ${ }^{46}$. Jestestwo jest swoimi możliwościami i jest tym faktycznie - chciałoby się rzec: ,już” jest, już jakoś się dzieje - ,dlatego, że jest ono tym, czym się staje lub nie staje, może ze zrozumieniem rzec samemu sobie: stań się tym, czym jesteś!’ ${ }^{47}$

b) Indywidualizacja: trwoga i śmierć

Trwoga jest pewnym sposobem bycia, który odsłania nieważność bytu wewnątrzświatowego, nicość wszystkiego sprowadza jestestwo do niego samego, do egzystowania w tej nicości dla siebie ${ }^{48}$; tym samym odsłania jego możliwości egzystencjalne. Trwoga umożliwia właściwe rozumienie siebie, zdanie na siebie wobec tego jest właściwą troską. Jestestwo w trwodze rozumie siebie jako rzucone tu i projektujące się poza siebie, zaczyna troszczyć się o swą egzystencję i o właściwe sobie (faktyczne) decyzje. Powraca wprawdzie do świata, ale może wracać do siebie.

Wybieganie ku śmierci (trwoga ${ }^{49}$ ) indywidualizuje ${ }^{50}$ jestestwo w samo siebie, a tym samym odcina je od siebie-Się, ujawniając zarazem owo wcześniejsze zatracenie w Się i projektowanie się na jego możliwości.

${ }^{45}$ Tamże, s. 206-207.

46 Tamże, s. 207.

${ }^{47}$ Tamże.

${ }^{48}$ Zob. E. Levinas, Odkrywajac egzystencję z Husserlem i Heideggerem, dz. cyt., s. 89.

${ }^{49}$ Bycie ku śmierci jest trwogą, ta zaś przebija się poprzez zgiełk Się w milczącym wezwaniu sumienia do samego Siebie (M. Heidegger, Bycie i czas, dz. cyt., s. 383). Głos sumienia to dawanie-do-rozumienia. Jestestwo jest dane sobie do zrozumienia - przekracza Się i oto Się znika, zostaje samo(tne) jestestwo w nieswojości braku Się. „Nieswojość ściga jestestwo i zagraża jego zapominającej o sobie zatracie" (tamże, s. 390). Jako dane sobie do zrozumienia nie jest dane sobie do psychologicznej samoanalizy ani do bycia z samym sobą, ale jest pozwaniem jestestwa ku jego możliwościom, pozwaniem „ku swej możności-bycia-Sobą” (tamże, s. 385). Wezwanie to może zostać zagubione „z racji oczekiwania użytecznej aktualnie informacji o stojacych do dyspozycji obliczalnych i gwarantowanych możliwościach «działania». To oczekiwanie opiera się na horyzoncie wykładni rozsądkowego zatroskania, który egzystowanie jestestwa wtłacza w ideę dającego się prowadzić interesu" (tamże, s. 412-413). Sumienie jednak o niczym takim nie informuje, nie wskazuje niczego ze strefy zatroskania, odbierając tym samym jestestwu możliwość działania, ale właśnie pozywa jestestwo do możności-bycia-Sobą.

${ }^{50}$ Zob. tamże, s. 270. Por.: „Śmierć indywidualizuje jestestwo w samo siebie” - „tam gdzie chodzi o najbardziej własną możliwość bycia zawodzi wszelkie bycie przy tym, o co się troskamy, oraz wszelkie współbycie z innymi. Jestestwo tylko wtedy może być właściwie soba, gdy samo z siebie sobie to umożliwi" - tamże, s. 370 . 
Wybieganie w bezwzględną możliwość wpędza wybiegający byt w możliwość podjęcia z samego siebie najbardziej własnego bycia na podstawie samego siebie. [...] Wybiegające wyzwalanie się ku własnej śmierci uwalnia od zatraty wśród przypadkowego natłoku możliwości, w tym mianowicie sensie, że dopiero ono pozwala właściwie rozumieć i wybierać faktyczne możliwości, które poprzedzają tę nieprześcignioną ${ }^{51}$.

Każde zatrzymanie się, zastygnięcie przy osiągniętej egzystencji, wszelka gotowość jest burzona przez wybieganie - w tym sensie wybieganie chroni jestestwo przed ,pozostaniem w tyle ze sobą samym" ${ }^{52}$.

Bycie ku śmierci nie jest jakimś oczekiwaniem śmierci - jestestwo nie ma czekać na śmierć, ale wybiegać w możliwość śmierci - śmierć jest „możliwością niemożliwości egzystencji w ogóle. Śmierć jako możliwość nie daje jestestwu niczego «do urzeczywistnienia»"53. Jestestwo „staje twarzą w twarz ze śmiercia, aby byt, którym samo jest, całkowicie przejąć w jego rzuceniu"54. Pozwólmy Heideggerowi rozjaśnić to jeszcze bardziej:

Możliwość ta nie daje żadnej podstawy do skupienia się na czymś [...]. Bycie ku śmierci jako wybieganie w możliwość umożliwia dopiero tę możliwość i wyzwala ją jako taką. Bycie ku śmierci to wybieganie w możność bycia tego bytu, którego sposobem bycia jest samo wybieganie. W wybiegającym odsłanianiu tej możności bycia jestestwo otwiera się samemu sobie ze względu na swą ostateczną możliwość. A projektować się na najbardziej własną możliwość bycia oznacza: móc rozumieć siebie samego w byciu tak odsłoniętego bytu: egzystować. Wybieganie okazuje się możliwością rozumienia najbardziej własnej ostatecznej możności bycia, tzn. możliwością egzystencji właściwej5.

Bycie ku śmierci jako wybieganie w (naszą najbardziej osobistą) możliwość tej śmierci umożliwia samą tę możliwość oraz wszelkie inne możliwości w ogóle - nadając jestestwu charakter możliwościowy, charakter egzystencji. W tym sensie jestestwo jako egzystujące, a przez to spełniające swą egzystencję (rozumiejące i wybiegające) jest stale ku śmierci56 - nie zaś przez obsesyjne myślenie o niej, przez posiadanie jej stale przed oczyma. Skończoność jest zatem warunkiem samej egzystencji jako wybiegania w możliwości, a także czasowości jako pędu ku możliwościom. Czas nie jest czymś, co jestestwo posiada, ono egzystuje czasowo.

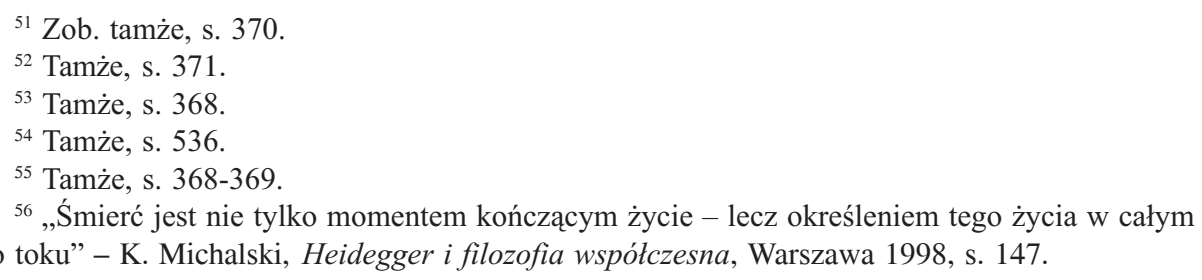




\section{c) Zdecydowane bycie-Sobą i faktyczne możliwości}

By rozjaśnić, co znaczy być-Sobą, należy przypomnieć, że w języku Heideggera rozumienie „w sensie pierwotnym nie oznacza przyglądanie się jakiemuś sensowi, lecz rozumienie siebie $\mathrm{w}$ możności bycia jaka odsłania się $\mathrm{w}$ projek-

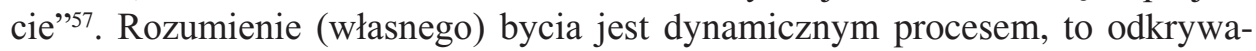
nie właściwego, bytowo-egzystencjalnego rozumienia siebie, i zdecydowanie się na siebie to popadanie w niewłaściwe, ontyczno-egzystencyjne rozumienie siebie i niezdecydowanie. Stąd rozumienie bycia ,kształtuje się lub rozpada odpowiednio do aktualnego sposobu bycia" ${ }^{58}$. "Tylko poprzez samo egzystowanie można się uporać z kwestią egzystencji' ${ }^{59}$. Tylko decydując się na siebie, można właściwie egzystować.

Zdecydowanie na siebie samego przemienia nas oraz nasz świat. Właściwa egzystencja we właściwy sposób otwiera całe bycie-w-świecie: „najbliższym faktycznym projektom [nadal - J.Ł.] przewodzi zatroskana zatrata w Się"60, a jednak jestestwo może zawsze wezwać samo siebie do bycia sobą: „ta właściwa otwartość modyfikuje wówczas w sposób równie pierwotny ufundowaną w niej odkrytość «świata», jak otwartość współjestestwa innych"61. Świat nie zmienia się co do zawartości, a kragg innych nie ulega wymianie, to nasze rozumienie i współbycie z innymi ulega zmianie: odtąd pozwalamy im być sobą - dopiero w ten sposób może wyrosnąć właściwa wspólnota ${ }^{62}$. Samo jestestwo zaś jest na sposób decydowania. Decydowanie to nie wybór spośród ,,przedkładanych i zalecanych" możliwości (jak czyni to człowiek żyjący z dnia na dzień), który zamyka owe możliwości (jako możliwości) - egzystencjalnie „to właśnie dopiero decyzja otwiera, projektuje i określa aktualna faktyczna możliwość" ${ }^{63}$.

„Do zdecydowania należy z konieczności nieokreśloność, która charakteryzuje każdą faktycznie-rzuconą możność bycia jestestwa" ${ }^{64}$. Zdecydowanie jest pewne siebie samego tylko jako decyzja. Nieokreśloność ta, jako taka, która określa się dopiero po decyzji, jest nieokreślona egzystencyjnie, egzystencjalnie zaś jest określona jako moja decyzja. „Zdecydowanie nie przedstawia sobie sytuacji rozpoznając ją dopiero, lecz już się w niej było postawiło. Jako zdecydowanie jestestwo już działa” ${ }^{65}$. „Wybiegające zdecydowanie [...] wypływa $\mathrm{z}$ trzeźwego rozumienia faktycznych podstawowych możliwości jeste-

\footnotetext{
${ }^{57}$ M. Heidegger, Bycie i czas, dz. cyt., s. 369.

${ }^{58}$ Tamże, s. 23.

${ }^{59}$ Tamże, s. 18.

${ }^{60}$ Tamże, s. 417.

${ }^{61}$ Tamże.

${ }^{62}$ Zob. tamże, s. 418.

${ }^{63}$ Tamże, s. 418-419.

${ }^{64}$ Tamże, s. 419.

65 Tamże, s. 421.
} 
stwa" ${ }^{66}$. „Możność bycia jest tym, ze względu na co jestestwo zawsze jest tak, jak faktycznie jest" ${ }^{67}$.

Podsumowując, warto przypomnieć, że jestestwo nie rozporządza swoją egzystencją $^{68}$, ale jest zdane na własne bycie. Jest skazane zarówno na rozumienie siebie jako możliwości, na dokonanie wyboru, jak i na stanie w kręgu zastanych możliwości. Bycie jestestwa nie jest czymś stałym, nie ma jakiejś stałej esencji, która pozwala mu pozostawać sobą wśród zmienności faktów - lecz jest czymś zmiennym, „dzieje się”. W tym dzianiu się jestestwo dopiero wychodzi na jaw ${ }^{69}$. Widzenie siebie jako możliwą do określenia i spełnienia całość jest widzeniem przedmiotowym - utrzymywaniem siebie w sferze bytu, którego istota (potencjał) zmierza do pełnej realizacji. Byt się staje i uspokaja się po osiagnnięciu celu - zaś bycie dzieje się. W określonym z góry projekcie egzystencyjnym pierwszeństwo nad dzianiem się uzyskuje to, co się dzieje $\mathrm{e}^{70}$. Tymczasem właściwym sposobem „realizacji” jestestwa jest bycie jako stałe wykraczanie poza siebie, otwartość, niedokonaność - dzianie się.

„Wybór sposobu bycia jest życiowym problemem każdego człowieka" ${ }^{\text {"11, }}$ dokonuje się na podstawie wiedzy egzystencyjnej. Rozstrzygnięcie egzystencyjne, nasz konkretny sposób bycia wpływa na stopień odsłonięcia lub skrycia samej egzystencji, a zatem właściwe egzystowanie i bycie sobą. To odsłonięcie nie dokonuje się teoretycznie, ale jedynie przez przekształcenie własnego sposobu bycia w taki sposób, by wyłonić z siebie problem bycia i rozjaśnić go przez właściwy sposób bycia. Ponieważ bycie jest moje, jest mi ono nieobojętne. Właściwy projekt egzystencjalny jest takim projektem, który ma trafić na bycie. Dopiero przez egzystencjalne rozumienie siebie, które jest tym samym, co właściwy sposób egzystowania, jestestwo właściwie projektuje siebie na swe możliwości. „To, czym człowiek jest, jest zarazem jego sposobem bycia”" W2. Właściwe egzystowanie jest tym samym jego właściwą odpowiedzią na pytanie ,jak żyć?”

${ }^{66}$ Tamże, s. 435. Skąd jestestwo ma brać swoje faktyczne możliwości? Im mniej dwuznacznie jestestwo wybiega w śmierć, tym bardziej jednoznacznie i nieprzypadkowo znajduje swoją własną możliwość bycia. To właśnie samo zrozumienie skończoności egzystencji „wyrywa z bezkresnej rozmaitości” możliwości i ujawnia nam tę możliwość, która jest najmniej przypadkowa i pobieżna. Zob. tamże, s. 537. Por. D. Goleman, Inteligencja emocjonalna, tłum. A. Jankowski, Poznań 2007, s. $59-60$.

${ }^{67}$ M. Heidegger, Bycie i czas, dz. cyt., s. 273.

${ }^{68}$ Zob. K. Michalski, Heidegger i filozofia współczesna, dz. cyt., s. 41.

${ }^{69}$ Zob. tamże.

${ }^{70}$ Zob. tamże, s. 57.

${ }^{71}$ Tamże, s. 45.

${ }^{72}$ E. Levinas, Odkrywajac egzystencję z Husserlem i Heideggerem, dz. cyt., s. 61. 


\section{Heideggerowskie rozumienie projektowania egzystencji a samotność}

Heidegger zauważa niebezpieczeństwo takiej charakterystyki spotykania innych, która orientowałaby się na „zawsze własne jestestwo" 73 w taki sposób, że zajęcie się jedynie sobą jako jakimś izolowanym ,ja" (monady) prowadziłoby do konieczności poszukiwania „przejścia od tak izolowanego podmiotu do innych"74. Dlatego podkreśla, że wspólne bycie nie jest jedynie jakimś współwystępowaniem pewnej liczby podmiotów w świecie - jakimś byciem obok siebie ale faktycznym byciem razem, dzieleniem pewnego świata oraz pewnej doli ${ }^{75}$. Dane jestestwo nie jest pierwotnie kimś izolowanym od innych, od tych, którzy stanowiliby dla niego jedynie rodzaj tła, od którego się odróżnia, jest wręcz przeciwnie: ,inni to raczej ci, od których się zwykle sam nie odróżniam i wśród których jestem" "76. Świat danego jestestwa to już zrazu w s półś w i a t, a jego bycie-w to ws półbyci e z innymi. Bycie człowieka, ,jest z istoty współbyciem"’77. Innych spotykamy już zrazu w otoczeniu, a nie dopiero wtórnie po pierwotnym ujęciu własnego podmiotu ${ }^{78}$, jest wręcz odwrotnie, pierwotnie znajdujemy się i spotykamy z innymi przy („tym samym”) świecie, dopiero wtórnie możemy „odizolować” się od współbycia z innymi - być osobno.

Samotność jest tylko pewną modyfikacją współbycia: kiedy we współbyciu brakuje innego (jest nieobecny) lub gdy spotykany jest na sposób obojętności i obcości ${ }^{79}$. Zarówno obojętność, jak i bycie dla siebie nawzajem, są odmianami troskliwości ${ }^{80}$. Troskliwość jest rodzajem troski skierowanym ku innym jestestwom (współjestestwom). Negatywna troskliwość (niepełna) ma tendencję do sprowadzania innych do poziomu czegoś poręcznego, do obojętności-na-siebienawzajem. Charakteryzuje ona powszednie i przeciętne wspólne bycie. Pozytywna (bo nieobojętna) troskliwość o drugiego może działać na dwa sposoby: odebrać lub zwrócić komuś troskę. Odbiera się troskę o coś, o co się ktoś troszczy (dbając o jego byt), zwraca się zaś troskę o jego własną egzystencję (dbając o egzystencję innego). Tak jak niewłaściwa troska o siebie troszczy się o to, co w świecie (co poręczne), podobnie troskliwość może troszczyć się o innych, troszcząc się dla nich o to, co poręczne (np. o chleb), gdy tymczasem właściwa troska (zatrwożona) o siebie, troszczy się o własne bycie, podobnie jak taka troskliwość wobec innych zwraca ich trosce ten sam kierunek - troskę o ich własne bycie $^{81}$ (bycie sobą ku własnej śmierci). Możemy pomóc innym we właściwym

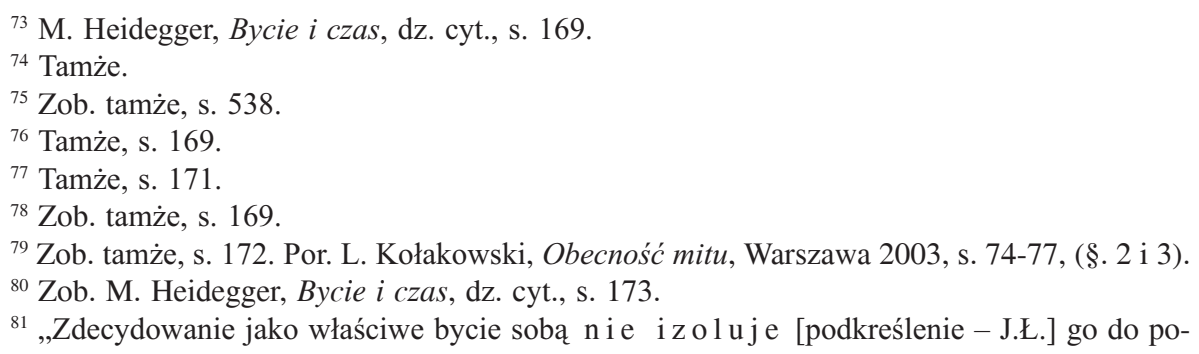


zrozumieniu egzystencji, nie możemy ich jednak w tym zastąpić. Nawet wspólne poświęcanie się tej samej sprawie (z pasja) jest „określone na podstawie zawsze na własny sposób uchwytywanego jestestwa" "82. Oznacza to, że właściwe współbycie, ,zespolenie” jest pewnym współdziałaniem dwóch niezależnych (samodzielnych) jestestw. Bycie, do którego jestestwo się odnosi w egzystencji, jest zawsze jego własne.

Współbycie z innymi jest czymś pierwotnym i zastanym (w rzuceniu), podobnie rozumienie innych jest egzystencjalnym sposobem bycia (współbycia), które to dopiero umożliwia poznawanie innych i wiedzę o nich. Pierwotnie rozumie się innych jako współużytkowników świata, jako będących przy tym świecie $^{83}$ - nie oznacza to jeszcze bycia blisko innego i postawa ta może być pełna rezerwy. Znajomość siebie nawzajem wymaga zatem poznawania się, zbliżenia, podejścia do innego. Podejście takie nie jest jakimś „wczuciem”. Wczucie w innego zakładało właśnie pierwotną osobność, zamknięcie, było próbą przełamania tego zamknięcia (monady), przerzucenia pomostu do wspólnoty z innym ${ }^{84}$.

staci oderwanego Ja. Jakże by mogło, skoro przecież jako właściwa otwartość nie jest właściwie niczym innym jak byciem-w-świecie? Zdecydowanie sprowadza Siebie właśnie w aktualne zatroskane bycie przy tym, co poręczne, i popycha je w troskliwe współbycie z innymi. [...] Dopiero zdecydowanie na siebie samo sprowadza je do możliwości, by pozwolić współbytującym innym «być» w ich najbardziej własnej możności bycia, tę zaś współotwierać w wychodzącej naprzeciw i uwalniającej troskliwości. Zdecydowane jestestwo może stać się «sumieniem» innych. Właściwa «wspólnota» wyrasta dopiero z właściwego bycia zdecydowanie Sobą, nie zaś z dwuznacznych i pełnych zazdrości układów, rozgadanych zbratań na łonie Się i z zamierzanych przedsięwzięć. [...] Całkowicie błędnie zrozumielibyśmy fenomen zdecydowania mniemając, że tylko sięga ono biernie po przedkładane i zalecane możliwości. To właśnie dopiero decyzja otwiera, projektuje i określa aktualnq faktycznq możliwość" (tamże, s. 418-419, por. s. 435). Jak się wydaje, wynika stąd, że nie jedynie poprzez trwogę, ale także w jakiś inny sposób, przez relację z kimś, kto potrafi zwrócić nam naszą troskę o własne bycie (staje się naszym sumieniem), możemy wejść na drogę właściwego bycia sobą. Świadczą o tym i inne słowa Heideggera: „Ta troskliwość, z istoty dotycząca właściwej troski, tzn. egzystencji innego, nie zaś czegoś, o co się on troska, p o m a g a [podkreślenie - J.Ł.] innemu przejrzeć siebie $w$ swej trosce i stać się wolnym ku niej” (tamże, s. 174). Okazuje się, że właściwie będące-Sobą, wolne jestestwo może pomagać innym w ich wyzwoleniu. Choć na ten temat Heidegger nie mówi już nic więcej, jak można przypuszczać, takie właśnie zadanie towarzyszyło mu podczas pisania Bycia i czasu.

${ }^{82}$ Tamże, s. 175.

${ }^{83}$ Jest jeszcze ,gorzej”, gdy już samo to pierwotne rozumienie jest niewłaściwe i innych rozumie się jako coś poręcznego - jako „przedmioty”, jako „numerki” - „to «bezwzględne» współbycie «rachuje» innych nie «licząc na nich» poważnie ani nawet nie chcąc «mieć z nimi do czynienia»" - tamże, s. 179.

${ }^{84}$ Jeśli przyjmie się, że pierwotnie podmiot jest dany sobie samemu samotnie, a dopiero później zaczyna szukać możliwości przedarcia się do innego zamkniętego podmiotu, problematyczna staje się możliwość samego zadzierzgnięcia takiego stosunku: przebicia się przez dwie granice (moją i cudza). Wczucie jako przebicie się przez taką monadyczność (solipsyzm) jawi się jako bardzo problematyczne, wręcz pozbawione podstaw. Taka perspektywa ostatecznie prowadzi do potrzeby dowodu istnienia innych ludzi poza mną. Por. tamże, s. 177. 
Stosunek jestestwa do jestestwa - relacja spotkania - wynika z pierwotnego współbycia, które nie potrzebuje przerzucać pomostu, który już zrazu jest przerzucony (w rzuceniu), ale jedynie przejść przezeń, zbliżyć się do drugiego. Jeśli pamiętając o tym, że człowiek zrazu jest wespół z innymi, nadal chcielibyśmy utrzymać ,wczucie” jako rozumienie innych poprzez rozumienie siebie, to byłoby ono pomocne jedynie wtedy, gdy pogłębiałoby rozumienie siebie właśnie jako kogoś istotowo współbędącego z innymi, a zarazem niezasłaniającego sobie tej „prawdy”. Wczucie ujawnia się wtenczas jako wtórne do współbycia. Mimo to problemem pozostaje, jak możliwe jest rzetelne rozumienie innego bez uciekania się do namiastek i wypaczenia znajomości siebie nawzajem. Jednak z samego faktu, że bycie jestestwa jest współbyciem, wynika możliwość „należytego rozumienia obcych" ${ }^{85}$. Kończąc 26. paragraf Bycia i czasu, Heidegger powraca do zagadnienia tego, jak napotyka się innych „zrazu i zwykle”, i w kolejnym paragrafie skupia się na analizie jedynie takiego właśnie powszedniego bycia $\mathrm{z}$ innymi (Się), nie powracając $\mathrm{w}$ dalszej części tekstu do spotkania jako właściwego rozumienia, bliskości i wspólnoty z innymi. Możliwość ta zostaje zatem raczej odłożona, postulowana i zarzucona jako poboczna w stosunku do głównego tematu ontologii: bycia w ogóle, nie zaś zanegowana ${ }^{86}$.

Co z tego wynika dla tematu samotności? Otóż, jeśli jestestwo pierwotnie jest zanurzone we wspólnocie, tak też siebie znajduje, kiedy trwoga wzywa je do bycia-Sobą. Bycie sobą w pewien sposób różni się od dotychczasowego (niewłaściwego) bycia wespół z innymi, jest pozytywną możliwością osobności - takiej samotności, która uwalnia od natłoku wrażeń oraz proponowanych (przez niewłaściwą wspólnotę: Się) możliwości - a zarazem jest warunkiem możliwości zdecydowanego projektowania się na własne możliwości ${ }^{87}$ - rezultatem czego staje się możliwość powrotu do tym razem już właściwego bycia z innymi (spotkania $^{88}$. Wynika stąd, że samotność jest pewnym (pozytywnym) medium pośredniczącym między niewłaściwym a właściwym byciem z innymi - jest samotnością przejścia ${ }^{89}$. Idąc drogą analityki jestestwa i biorąc pod uwagę, że zarówno

\footnotetext{
${ }^{85}$ Tamże, s. 178.

${ }^{86}$ Nie miałby wówczas racji Kamil Sipowicz, mówiąc, że ,inny u Heideggera nie ma szansy przekształcić się w obcego. Jest jakby «przycięty» do tego, co wykonuje. Od razu przemienia się w bezosobowe Się" - K. Sipowicz, Heidegger: degeneracja i nieautentyczność, Warszawa 2005, s. 184.

${ }^{87}$ Por. przyp. 65.

${ }^{88}$ Stałoby to wbrew zarzutowi pod adresem Heideggera, o to, że dokonująca się w jego namyśle fiksacja na poziomie dążenia do bycia sobą powoduje zapomnienie o innych.

${ }^{89}$ Jeśli rozumieć ową kolistość wyjścia z Się do samotności i powrót do wspólnoty jako proces - uprawnione byłoby przyrównanie go do rozwoju osobistego. Punktem wyjścia w rozwoju jest „ja” jako centrum, wraz z rozwojem wartościowanie skrajnie subiektywne i egoistyczne przewartościowuje się w kierunku większej obiektywności oraz alterocentryzmu. Zob. E. Sujak, Rozważania o ludzkim rozwoju, dz. cyt., s. 28-29.
} 
właściwe bycie sobą (sobość), rozumienie siebie, autentyczność (mojośćco bycia i możliwości), zdecydowanie (samodzielność), a ostatecznie także, jak się zdaje, autentyczne spotkanie $\mathrm{z}$ innymi ${ }^{91}$, możliwe jest dopiero wówczas, gdy jestestwo wydobędzie się $\mathrm{z}$ roztopienia $\mathrm{w}$ byciu na sposób wszystkich i zindywidualizuje się, a zatem jedynie poprzez (zatrwożona) samotność, trudno nie uznać jej za warunek właściwego projektowania egzystencji.

Samotność taka nie jest „totalnym” egoizmem podmiotu, dla którego liczy się jedynie on $\mathrm{sam}^{92}$, podobnie jak niezapominanie o sobie jako warunek bycia autentycznym, nie jest narcyzmem ${ }^{93}$. Zwykło się zarzucać Heideggerowi, że jego ujęcie autentycznej egzystencji (bycia soba) jest ściśle związane z całkowitym skupieniem się na sobie, zamknięciem w sobie, które uniemożliwia człowiekowi nieinstrumentalną relację z innymi. Tymczasem, jak się zdaje, to właśnie potoczne rozumienie koncepcji Heideggera spopularyzowane przez Sartre'a wpędza człowieka w bycie taką egoistyczną „monadą”. Według Sartre’a człowiek szuka oparcia we własnej wolności, neguje to, co niesie świat, nieustannie z nim walczy, by dowieść własnej wolności, bycia dla siebie. Przypomina to Heideggerowskie właściwe bycie w trwodze, która odrywa nas od bytu - a przecież po to tylko by odsłoniło się nam jego bycie. Taka postawa egzystencjalna nie ma na celu przeciwstawiania się światu i walki z nim w imię jakiejś absolutnej niezależności bycia kimś nie z tego świata (bycia-dla-siebie), ale właśnie kimś, przez kogo bycie tego świata może przeświecać, kimś, kto je ujawnia i troszczy się o nie. Heidegger zwraca uwagę na to, że człowiek spontanicznie odnosi się do bycia, troszczy się o nie, mając potrzebę zrozumienia go, wydobywa je na jaw, nadaje temu, co go otacza, sens, ale też przecież zastaje to jako coś, co już jest (było), na co został zdany ${ }^{94}$. „Bycie Dasein określone jest przez potrzebę i konieczność ${ }^{995}$. Mamy potrzebę nadać sens temu, co zastajemy wokół nas. Zrozumienie

${ }^{90}$ M. Heidegger, Bycie i czas, dz. cyt., s. 59.

${ }^{91}$ Por. „Trzeba mocno tkwić w s o bi e, trzeba dzielnie stać na obu nogach, inaczej nie mo ż n a kochać" - F. Nietzsche, Ecce Homo. Jak się staje - kim się jest, tłum. L. Staff, Kraków 2004, s. 38 .

${ }^{92}$ Na przykład: „Właściwe bycie Sobą właśnie jako milczace nie mówi: «Ja, Ja», lecz w tym milczeniu «jest» rzuconym bytem, którym może być właściwie. [...] Ontologiczne pytanie o bycie Siebie trzeba uwolnić od ciagle sugerowanego przez dominujące mówienie-Ja wyjściowego obrazu Siebie trwale obecnego w postaci rzeczy. Troska nie potrzebuje ufundowania $w$ Sobie" M. Heidegger, Bycie i czas, dz. cyt., s. 453.

${ }^{93}$ Zapomnienie o sobie polega na zapomnieniu własnej byłości, korzeni - wynika $\mathrm{z}$ tego błędne rozumienie siebie oraz niewłaściwe projektowanie się na możliwości. Jestestwo nie może przyjść-do-siebie, jeśli siebie zapomniało (zob. tamże, s. 475-476). Niezapominanie o sobie nie jest stałością egocentryzmu, obsesją na swoim punkcie uniemożliwiającą bezinteresowny czyn.

94 „Rzeczą jego [jestestwa - J.Ł.] wolności, choć zawsze w granicach jego rzucenia, jest tylko, co ono aktualnie odkrywa i otwiera, w jakim kierunku, jak dalece i w jaki sposób" - tamże, s. 513.

${ }^{95}$ K. Michalski, Heidegger i filozofia wspótczesna, dz. cyt., s. 139. 
jako skończone jest niezaspokajalne, niespokojne - jest podejmowaniem wciąż na nowo tego, co już znane, podejmowaniem świata, wysiłkiem na rzecz tego świata i godzeniem się z nim. Według Heideggera bycie sobą jest byciem-w-świecie, afirmacją, współbyciem (wspólnotą ${ }^{96}$ ) ze światem, choć na warunkach własnego rozumienia, zdaniem Sartre’a zaś, człowiek dla-siebie jest zawsze przeciw światu, który stawia mu opór, światu, którego nie da się zrozumieć: walka $\mathrm{z}$ absurdem świata wydaje się z istoty walką z wiatrakami, nieustanną niezgodą i buntem ${ }^{97}$.

Jakie to ma znaczenie dla projektu egzystencjalnego? Otóż Heideggerowski projekt okazuje się czymś różnym od wywalczania sobie przemocą wobec świata spełnienia własnej wolności i dokonywania zgodnie $\mathrm{z}$ jej postanowieniami, projekt jest zaangażowaniem $\mathrm{w}$ świat wynikającym z potrzeby określenia sensu egzystencji w tym świecie. Sens ten jest poszukiwany jako coś, co obchodzi nas najbardziej, szukamy sensu bycia, gdyż samo bycie jest naszym zadaniem do realizacji - szukamy tego sensu, będąc. Możliwości naszego bycia nie są czymś naszym, co rzucamy (projektujemy) przed siebie w sposób wirtualny, a następnie za pomocą jakiejś strategii i środków urzeczywistniamy przez wypełnienie (dojście do tego), możliwości bycia tkwią w aktualności samego jestestwa w taki sposób, że już zrazu jest w nich pogrążone a zarazem otwiera coś jako możliwość, decydując się na nią. „W otwartości «tu oto» współotwarty jest świat”98.

Wedle Heideggera $\mathrm{z}$ tego, że bycie jest naszą własną sprawą, nie wynika zamknięcie w sobie, nie skazuje nas to także na egocentryzm - a jedynie wskazuje na kondycję ludzką: egzystencję. Najbardziej własną możliwością jestestwa jest bycie. Śmierć jest jego skrajną możliwością - możliwością niebycia. Owa podstawowa możliwość bycia jest z nią stale konfrontowana. Uciekamy od możliwości śmierci, ale tylko dlatego, że pojęliśmy ją jako możliwość. Kiedy egzystujemy, śmierć odsłania się coraz bardziej jako możliwość: zakrywamy to i znów odsłaniamy. Proces bycia (egzystencja) ma charakter możliwości - to że jestem tu i teraz, ale mogę nie być - kieruje to rozumienie na bycie po prostu, na samo bycie tu-oto. Autentyczne bycie (sobą) jest projektowaniem siebie ku śmierci w aktualności bycia tu-oto.

Otwartość, konstytuowaną przez nastrojenie trwogi i rozumienie jako wybieganie-ku-śmierci Heidegger nazywa zdecydowaniem. Zdecydowanie to autentyczna postawa życiowa. Postawa umożliwiająca autentyczne otwarcie Dasein na świat. Jest więc nie

96 „Jestestwo egzystując jest swoim światem”- M. Heidegger, Bycie i czas, dz. cyt., s. 511.

${ }^{97} \mathrm{O}$ ile Sartre doprowadził do ostateczności zachodni indywidualizm z jego poczuciem osobistej sprawczości (absolutnej wolności), to Heidegger, jak się zdaje, bliższy jest holistycznej myśli wschodniej. Dasein jest niesprowadzalne do wyizolowanego ,ja”, nie jest jakimś niezależnym podmiotem, ale podległym - nastrojom, kontekstowi Się, relacjom z innymi - procesem. Zob. R.E. Nisbett, Geografia myślenia, dz. cyt., s. 13, 19-36.

${ }_{98}$ M. Heidegger, Bycie i czas, dz. cyt., s. 511. 
tyle odwróceniem Dasein od tego, co jest w świecie, i zwróceniem się ku sobie, by w ten sposób być sobą autentycznie, lecz raczej - autentycznym kontaktem Dasein z tym, co jest w świecie. To dopiero zdecydowanie wprowadza Dasein w autentyczne zatroskanie i współbycie z innymi ${ }^{99}$.

Otwartość na świat jest właściwym projektem jestestwa. Otwartość ta wydarza się tu-oto w horyzoncie całej czasowości.

Wraz z faktycznym byciem-tu-oto jest zawsze w horyzoncie przyszłości zaprojektowana możność bycia, w horyzoncie byłości jest otwarte „bycie-już”, a w horyzoncie współczesności jest odkryty obiekt zatroskania. Horyzontalna jedność schematów ekstaz umożliwia źródłowy związek stosunków typu „ażeby” z ,ze względu na”. A zatem: na gruncie horyzontalnego ukonstytuowania ekstatycznej jedności czasowości do bytu, który jest zawsze swym „tu oto”, należy coś takiego jak otwarty świat ${ }^{100}$.

Gdybyśmy mieli przełożyć takie otwarcie na grunt psychologiczny, właściwe otwarcie na świat byłoby tym, co Philip Zimbardo i John Boyd nazwali „teraźniejszością holistyczną”. Teraźniejszość taka jako absolutna „zawiera w sobie zarówno przeszłość, jak i przyszłość"101, jest pełnym otwarciem na chwilę bieżąca, jest takim rodzajem przytomności (mindfullnes), które zastępuje linearne poczucie czasu poczuciem jego jedności. Jako taka jest ona zarazem zachowaniem stałej świadomości śmiertelności oraz zaangażowanym w teraźniejsze przeżywanie życia wykraczaniem w przyszłośćc ${ }^{102}$. Jestestwo i jego świat dzieją się. Każda chwila jest przesycona śmiercią, każda chwila jest otwarta na zmianę, każda chwila rozstrzyga sens życia.

\section{UWAGA KOŃCOWA}

W ten sposób zostały przedstawione dwa sposoby rozumienia tego, czym jest projektowanie egzystencji, zostały także ukazane różnice między oboma podejściami dotyczące fundamentalnych dla takiego projektowania zagadnień: skończoności życia i bycia wobec śmierci, projektowania się w przyszłość, wolności oraz odpowiedzialności za właściwe egzystowanie (projektowanie), zależności/ /niezależności spełnienia własnego projektu od innych, a wreszcie zagadnienia

\footnotetext{
${ }^{99}$ K. Michalski, Heidegger i filozofia wspótczesna, dz. cyt., s. 156-157.

${ }^{100}$ M. Heidegger, Bycie $i$ czas, dz. cyt., s. 511-512.

${ }^{101}$ Ph. Zimbardo, J. Boyd, Paradoks czasu, dz. cyt., s. 97.

${ }^{102}$ Por.: „W drodze bywa się zawsze tylko w jednym aktualnym miejscu, przejścia, w rozwoju zaś jest się zawsze zarówno w punkcie dojścia, jak i we wszystkich punktach przebytych i w punkcie wyjścia. Nie pozostawia się ich «poza sobą», raczej zbiera się je «w sobie». [...] Rozwój nakłada, nawarstwia na siebie kolejne punkty dojścia, ale jesteśmy zawsze we wszystkich punktach przebytych od samego początku” - E. Sujak, Rozważania o ludzkim rozwoju, dz. cyt., s. 27.
} 
bycia sobą ${ }^{103}$. Pomimo ważkich różnic oba rozumienia projektu egzystencjalnego jako propozycja odpowiedzi na pytanie ,jak żyć?”, roszcząca sobie pretensje do bycia właściwą odpowiedzią, wypływają z tego samego paradygmatu myślenia o człowieku, przede wszystkim jako kogoś osobnego, wyróżniającego się osobistym zadaniem, które ostatecznie jedynie on sam może „odkryć” (przystać na nie) i samodzielnie zrealizować (być soba). Człowiek jako niezastapiony (nikt go nie zastapi ani on nie zastapi nikogo) w swojej egzystencji jest dla siebie największym problemem i zadaniem (projektem) na całe życie - zadaniem z gruntu samotnym i pochłaniającym.

Cała konstrukcja projektu egzystencjalnego w obu rozumieniach opiera się ostatecznie na tym samym sposobie rozumienia kondycji ludzkiej jako nade wszystko naznaczonej przez śmierć, przez skończoność. Zarówno potoczna panika intensyfikacji wrażeń i dokonań, jak i Heideggerowska egzystencja (jako wybieganie ku możliwościom, a przecież tylko dzięki tej ostatecznej i zawsze też ku niej), przeniknięte są perspektywą śmierci. Orientacja na śmierć określa sam sposób naszego egzystowania na sposób projektowania przyszłości. To dzięki śmierci możemy przechwycić własne rzucenie. To dzięki śmierci jesteśmy przyszłościowi. Orientacja na śmierć, na naszą własną śmierć, orientuje nas na siebie samych, na nasze własne bycie - czyniąc tym samym samotność czymś koniecznym nie tylko dla bycia sobą, ale dla kondycji ludzkiej w ogóle.

„Filozofia Heideggera jest więc próbą ustanowienia osoby jako miejsca, w którym spełnia się rozumienie bycia, bez jakiegokolwiek oparcia w wieczności. W czasie źródłowym, w byciu ku śmierci, warunku wszelkiego bycia, egzystencja odkrywa nicość, na której się opiera, co znaczy także, że nie opiera się na niczym poza sobą"104. Jeśli Emmanuel Levinas krytykuje całość koncepcji Heideggera za jej „egocentryzm”, to ma nade wszystko na myśli jej podstawę, jaką jest pochłonięcie przez skończoność. W tym sensie nie jest istotne to, czy jestestwo, będąc-Sobą, potrafi, czy nie, dbać o innych, spotkać innego i rozumieć go (która to możliwość, mam nadzieję, udało mi się ukazać), ale to, że dla skończonego jestestwa będzie to zawsze spotkanie $\mathrm{z}$ innym skończonym jestestwem, na tej samej płaszczyźnie, spotkaniem, które nie może być spotkaniem z nieskończonością. Dlatego Levinas powie: „być sobą, być ateistą, być u siebie, być oddzielonym, być szczęśliwym, być stworzonym - oto synonimy" ${ }^{\prime 105}$.

Separacja jest według Levinasa wolą bycia sobą, u siebie, w swej intymności, jest zamknięciem na innych, na nieskończoność, dopiero rozdarcie tej całości, jaką człowiek sobie stworzył, umożliwia spotkanie z innym. Z perspektywy

${ }^{103}$ Bycia sobą poprzez zaprojektowanie i zrealizowanie dokonań w różnicy do bycia sobą na sposób ,aktualizacji” swoich najbardziej własnych możliwości bycia.

${ }^{104}$ E. Levinas, Odkrywajac egzystencje z Husserlem i Heideggerem, dz. cyt., s. 94.

${ }^{105}$ Tenże, Całość i nieskończoność. Esej o zewnętrzności, tłum. M. Kowalska, Warszawa 2002, s. 169. 
nieskończoności projektowanie egzystencji nie jest wynikiem wysokiej samoświadomości związanej z chęcią dobrego i właściwego ludzkiej kondycji przeżycia życia, ale wynikającą ze złego rozumienia tej kondycji rozpaczliwą próbą nadania przez siebie samego (czyli to, co skończone) własnemu (skończonemu) życiu sensu - jest pewnym sposobem bycia, który należałoby przezwyciężyć. Dla Levinasa człowiek „nie jest bytem ku śmierci, lecz przede wszystkim tym, który jeszcze nie umarł"106 - skupiającym się bardziej na życiu i jego radościach niż na powadze tragicznej nieuchronności śmierci - dlatego też, według niego, skończoność jest błędnym fundamentem rozumienia człowieka. Ukazanie przeciwnego człowiekowi projektującemu się człowieka spontanicznego wymagałoby zatem odmiennej ontologii jestestwa czy wręcz wyjścia poza/ponad taką ontologię w ogóle. Nie rozstrzygając o tym, czy Levinas faktycznie przezwyciężył myślenie Heideggerowskie, ani o tym, „kto ma rację”, chciałbym na koniec zauważyć, że poprzez sam ów spór zagadnienie samotności/separacji znalazło się w obszarze, w którym próbuje się rozstrzygać to, co właściwie znaczy bycie człowiekiem.

\section{BIBLIOGRAFIA}

Bauman Z., Sztuka życia, tłum. T. Kunz, Kraków 2009.

Dennett D.C, Odczarowanie. Religia jako zjawisko naturalne, tłum. B. Stanosz, Warszawa 2008.

Goleman D., Inteligencja emocjonalna, tłum. A. Jankowski, Poznań 2007.

Heidegger M., Bycie i czas, tłum. B. Baran, Warszawa 1994.

Filek J., Filozofia jako etyka. Eseje filozoficzno-etyczne, Kraków 2001.

Kołakowski L., Obecność mitu, Warszawa 2003.

Levinas E., Odkrywajac egzystencję z Husserlem i Heideggerem, thum. E. Sowa, M. Kowalska, Warszawa 2008.

Levinas E., Całość i nieskończoność. Esej o zewnętrzności, tłum. M. Kowalska, Warszawa 2002.

Michalski K., Heidegger i filozofia współczesna, Warszawa 1998.

Nistbett R.E., Geografia myślenia, tłum. E. Wojtych, Sopot 2009.

Nietzsche F., Ecce Homo. Jak się staje - kim się jest, tłum. L. Staff, Kraków 2004.

Pascal B., Myśli, tłum. T. Żeleński (Boy), Warszawa 2000.

Pietrasiński Z., Rozwój z perspektywy podmiotu, w: Rozwój psychiczny człowieka w ciagu zycia. Zagadnienia teoretyczne i metodologiczne, red. M. Tyszkowa, Warszawa 1988, s. $80-118$.

${ }^{106}$ Zob. B. Skarga, Wstęp, s. XXVI, w: E. Levinas, Całość i nieskończoność. Esej o zewnętrzności, tłum. M. Kowalska, Warszawa 2002. 
Sipowicz K., Heidegger: degeneracja i nieautentyczność, Warszawa 2005.

Skarga B., Wstęp, w: E. Levinas, Catość i nieskończoność. Esej o zewnętrzności, thum. M. Kowalska, Warszawa 2002.

Sujak E., Rozważania o ludzkim rozwoju, Kraków 1998.

Zimbardo Ph., Boyd J., Paradoks czasu, tłum. A. Cybulko, M. Zieliński, Warszawa 2009.

\section{ABSTRACT}

The author, following Heidegger's analysis of Dasein way, starts with a description of common understanding of a project of existence. Then he passes on to its ontological understanding. Both common and Heidegger's way of understanding treat these issues in a different way. Despite significant differences, both ways of understanding the existence project - as a suggested answer to "how to live" question claiming to be the right ones - result from the same paradigm of viewing a human-being, mostly as somebody apart, who is distinguishable by possessing a self-imposed task, which could be "discovered" and put into reality only by an entity alone - and be oneself. Such a human, as a unique in his existence, is his own biggest problem and a task (a project) for all life.

\section{Keywords}

life, project of existence, time, meaning of life, human being, solitude, angst, death, freedom

\section{Słowa kluczowe}

życie, projektowanie egzystencji, czas, sens życia, człowiek, samotność, trwoga, śmierć, wolność 